\title{
Role of Work Environment and Organizational Culture To Job Performance
}

\author{
Arif Rachman Putra \\ Mila Hariani \\ Dita Nurmalasari \\ Moch. Irfan \\ Yusuf Rahman Al Hakim
}

\begin{abstract}
Improving the quality of human resources is focused on a variety of things that can affect job performance. There are two variables that are thought to have contributed to the formation of job performance, namely the work environment and organizational culture. This study aims to analyze and determine the effect of the work environment and organizational culture on job performance. The research will be conducted in one of the micro businesses in Kranggan District, Mojokerto Regency which involves 25 employees to be involved as respondents. Multiple linear regression analysis is used as an analytical tool to prove the research hypothesis. The research findings suggest that (1) the work environment has a significant effect on job performance; (2) organizational culture has a significant effect on job performance; and (3) work environment and organizational culture simultaneously have a significant effect on job performance.
\end{abstract}

Keywords: work environment, organizational culture, job performance

\section{Abstrak}

Peningkatan kualitas sumber daya manusia difokuskan kepada beragam hal yang dapat memengaruhi kinerja pegawai. Ada dua variabel yang diduga memiliki kontribusi terhadap pembentukan kinerja pegawai, yaitu lingkungan kerja dan budaya organisasi. Penelitian ini bertujuan untuk menganalisis dan mengetahui pengaruh lingkungan kerja dan budaya organisasi terhadap kinerja pegawai. Penelitian akan dilakukan di salah satu usaha mikro yang ada di Kecamatan Kranggan Kabupaten Mojokerto yang melibatkan 25 pegawainya untuk dilibatkan sebagai responden. Analisis regresi linear berganda digunakan sebagai alat analisis untuk membuktikan hipotesis penelitian. Dari temuan penelitian menyatakan bahwa (1) lingkungan kerja berpengaruh signifikan terhadap kinerja pegawai; (2) budaya organisasi berpengaruh signifikan terhadap kinerja pegawai; dan (3) lingkungan kerja dan budaya organisasi berpengaruh signifikan secara simultan terhadap kinerja pegawai.

Kata-kata kunci : lingkungan kerja, budaya organisasi, kinerja pegawai 


\section{INTRODUCTION}

Human resources are essentially one of the capital and play a very important role in the success of the organization. Employees are the main assets of the organization and have a strategic role in the organization. Those who contribute to the formation of organizational performance. In addition, a very complex internal factor that influences organizational performance is organizational culture. As human resources, the work lives of employees are greatly influenced by organizational culture. Organizational culture refers to a system of shared meanings shared by members that distinguishes the organization from other organizations. This system of shared meaning, when examined more closely is a set of key characteristics that are held in high esteem by the organization. Organizational culture has a considerable influence on job performance.

Improving the quality of work in the workplace is a critical aspect and is one of the organizational performance that is very important for achieving increased productivity, effectiveness, and efficiency of the organization. The key to the success of quality work life usually lies in cultural readiness. A feedback information becomes very important and the changes in the organizational environment have an influence to develop the quality of work life. Organizational management efforts in accordance with the needs of the implementation of the mission and objectives of the organization are very dependent on the management strategy of a broader work culture in the form of a human resource management strategy in the face of change. In addition, organizational culture helps leaders understand that in conceptualizing organizational culture, it is necessary to consider the people and environment of the organization as a complementary part of an organization. The essence of organizational change is directed at planned and systematic changes starting from changes in the structure and systems within the organization as a whole, as well as changes in the external environment that lead to efforts to improve organizational effectiveness in accordance with cultural development and scientific and technological progress (Schein, 1996).

Conflict that may occur due to organizational culture and work environment that tends to change is a phenomenon of conflicting interests in the context of organizational behavior that results in a decrease in the level of job performance. The greater challenge is when employees begin to exhibit negative behaviors that cause a decrease in work productivity such as loss of employee loyalty to the organization, loss of work motivation, to complete their duties an employee tends to make mistakes and reduce employee discipline by often not being present for various reasons. In addition to the negative influence of organizational change is expected to provide economic benefits for the organization, can improve communication relationships that are more harmonious between superiors and subordinates as well as communication between fellow colleagues is expected to run effectively and efficiently so that later can reduce conflicts that occur and can improve jobs employee performance.

A pleasant work environment for employees through binding harmonious relationships with superiors, coworkers, and subordinates, and supported by adequate facilities and infrastructure in the workplace will have a positive impact on employees so that job performance can improve (Saidi et al., 2019). The work environment has a very important role to support the organization of organizational activities. A comfortable work environment is a key driver for employees to produce optimal performance. Organizations must provide an adequate work environment such as the physical environment (comfortable office layout, clean environment, good air exchange, color, adequate lighting), as well as non-physical environment (relationships with superiors, relationships between colleagues, relations with subordinate). 
To create optimal performance, optimal work improvement is needed and is able to utilize the potential of human resources owned by employees to create organizational goals. In this case the role of the organization is needed in enhancing organizational culture and creating a conducive work environment to encourage the creation of professional attitudes and actions to complete work in accordance with their respective fields and responsibilities. The performance of individual employees greatly influences the success of an organization. Good job performance will cause organizational performance to increase (Sinambela et al., 2019). With the support of good governance to improve the culture of the organization and an adequate work environment can provide a better performance boost for employees so that the organization can achieve its expected goals (Dobre, 2013).

Based on the background of the problems outlined earlier, the writer tries to take the research topic with the research title as follows: "The Role of Work Environment and Organizational Culture on Job Performance." The research will be conducted in one of the micro businesses in the District Kranggan Mojokerto Regency. This research topic shows the objectives to be achieved in this study are as follows: (1) to determine the effect of the work environment on job performance; (2) to determine the effect of organizational culture on job performance; (3) to determine the effect of work environment and organizational culture simultaneously on job performance.

\section{LITERATURE REVIEW}

\section{Work environment}

A good work environment will create a good working atmosphere, which in turn has an impact on job performance. Gunawan (2017) states that the work environment is everything that exists around a worker and that can influence him to carry out the tasks assigned to him. This is like a number of physical components such as work space, equipment and work equipment and so on. In addition, non-physical matters, such as the atmosphere of calm, comfort, beauty and beauty of the room, the adequacy of light and also includes the relationship with social interactions that occur at work. Thus, the work environment is essentially a situation and conditions that are around the workplace. Another opinion states that there are two important aspects that must be considered from the work environment, namely the workplace itself and the treatment received from management. Employees feel that certain working conditions are pleasant when they do something useful that provides a sense of personal benefit. Thus, the work environment created plays an important role in the organization's ability to achieve its goals (Mahyanaila, 2016). Schultz and Schultz (2006) state the work environment is a condition that characterizes the workplace against employee behavior and attitudes related to the changing situation in the workplace. By creating a healthy and conducive work environment that can improve job performance to work more optimally, this can directly improve the quality of their work better. With a good work environment, this will make employees use their time effectively to complete their work as best they can if the work environment is supportive, otherwise if the work environment is inadequate it will degrade the employee's performance.

According to Jain and Kaur (2014), work environment has several main aspects, namely social aspects, mental aspects and physical aspects. Darmawan (2019) stated that important factors that need to be considered in an organization's work environment are equipment and facilities, work atmosphere, and workplace conditions. According to Darmawan (2013) such indicators to measure the work environment are (1) lighting; (2) air circulation; (3) noise; (4) 
security at work; and (5) employee relations. The work environment is very influential on the work activities of employees in the organization. In addition the work environment also has the opportunity to influence the most important factors such as efficiency, productivity, work motivation, job performance and job satisfaction. The organization must really pay attention seriously to the work environment to support the continuity of the organization.

\section{Organizational culture}

According to Kast and Rosenzweig (1990) organizational culture is an important set of values, beliefs and understandings shared by its members. The values or ideas and beliefs that are shared by the members are manifested in symbolic symbols such as myths, ceremonies, stories, legends and special languages. Kreitner and Kinicki (2005) state organizational culture as a form of perception that is owned and can be logically accepted to determine what employees think and react to a diverse environment. Organizational culture in an organization serves as a guideline for employee behavior in their daily work routines so as to lead employees to work. Organizational culture includes solid guidelines that shape behavior. Organizational culture carries out several important functions such as; conveys a sense of identity for the members of the organization, facilitates commitment to something greater than oneself, increases social stability, and provides a basis for opinions held and accepted for decision making. Gunawan (2017) states that organizational culture is everything that includes beliefs, attitudes and values held in an organization. Organizational culture in every organization has a function to form a system of the norm values of a new organization and can be developed to smooth an organization's goals. Darmawan (2013) states that organizational culture as a set of assumptions or belief systems, values and norms developed in organizations that serve as guidelines for behavior for members to overcome the problem of external adaptation and internal integration. Organizational culture as input consists of the founder of the organization, the owner of the organization, HR, stakeholders and the community.

According to Schein (2004) the process of cultural formation is closely related in a characteristic identical to the process of group formation which is very important in 'the group' or the characteristics of groups - patterns of division of thoughts, beliefs, feelings and values resulting from the sharing of experience and collectively is what is meant by the cultural end result of the group, without a group there will be no culture, and without a little culture we only talk about groups of people, not "the real group" so that group growth and cultural formation can be seen in two sides of the same coin and both come from leadership activities. Luthans (2011) provides a description of the characteristics of organizational culture, namely: (a) rules of behavior that provide guidelines for relationships between organizational members, communication, terminology, and ritual; (b) norms, in the form of written rules that guide how to work; (c) dominant values, containing clear conceptions or beliefs about things that are desired by members of the organization, such as conceptions of values about quality, high efficiency, low absenteeism, and so on; (d) philosophy, relating to organizational policies regarding how to treat members of the organization and other interested parties; (e) regulations, containing instructions on carrying out tasks in the organization; (f) organizational climate, describing the physical environment of the organization, the behavior of relationships between organizations, as well as organizational relationships with parties outside the organization.

Organizational culture is a controller that can shape attitudes and behaviors that involve employees in organizational activities. Organizational culture also functions to take into account the results achieved in the activities of the organization around the teams, because it is not only seen in individual employees to support collaboration. Indicators of organizational culture 
according to Denison and Mishra (1995) such as, (1) mission; (2) consistency; (3) adaptation; and (4) involvement. Culture has a positive influence on the organization if it raises behavior in the right direction (goal), permeates it widely on members of the organization and puts strong pressure on the organization to follow the culture that has been set. Sebalknya, culture negatively affects the organization if it results in the wrong direction. The company's organization has its own organizational culture which is the guideline of the members of the organization to carry out internal and external life, and this holding will influence the workings of the organization's members.

\section{Job Performance}

Performance is the actions or implementation of tasks or work that has been completed by someone within a certain period of time and it can be measured and standardized (Mahyanaila, 2016). Thus the statement shows the quality and quantity of work that can be completed individually within a certain period. Darmawan (2019) states that performance is the result achieved by someone according to the applicable measures of the job or task for which they are responsible. Usually people with high performance are referred to as productive people, and conversely people whose levels do not reach the standards are said to be unproductive or low-performing. Gunawan (2017) states that performance is the ability of someone trying to achieve better or more optimal work towards the achievement of goals. Job performance is a driving force for increasing work productivity and achieving organizational goals (Sinambela et al., 2019). Basically the purpose of their work will greatly affect their awareness to be able to improve their respective performance. Without good performance at all levels of the organization, the achievement of goals and organizational success becomes difficult and even impossible.

To know job performance, there is a need for standards or benchmarks mentioned by Gunawan (2017), namely the quantity, quality and timeliness of work. Performance evaluation aims to be known with certainty whether the achievement of results, progress and obstacles encountered in carrying out the mission can be assessed and studied to improve the implementation of tasks in the future. Darmawan (2019) sets six dimensions to measure performance, namely: (1) quality, related to the results of the implementation of activities that are nearing perfection or approaching the expected goals; (2) quantity, related to the amount produced, can be measured by the unit, the rupiah, or the cycle of activities completed; (3) timeliness, taking into account other output conditions and the time available for other activities; (4) cost effectiveness, the extent to which the use of organizational resources (human, financial, technological, material) is maximized to achieve the highest yield or reduction in losses from each unit of resource use; (5) need for supervision, the extent to which an employee performs work functions without requiring the supervision of a supervisor to prevent actions that are less desirable for the organization; (6) interpersonal impact, is the degree to which an employee maintains self-esteem, good name and cooperation with colleagues and subordinates. Performance appraisal is the process through which organizations assess job performance. Basically job performance appraisal is a systematic assessment of the work performance of the employee and of the potential level of the employee in his efforts to develop himself for the benefit of the organization. So if the performance appraisal is carried out properly, correctly and in an orderly manner it can help increase work motivation. 


\section{Research Conceptual Framework and Hypothesis}

This research will look for the influence of work environment and organizational culture partially and simultaneously on job performance. For this purpose the conceptual framework of the study is shown in Figure 1 below.

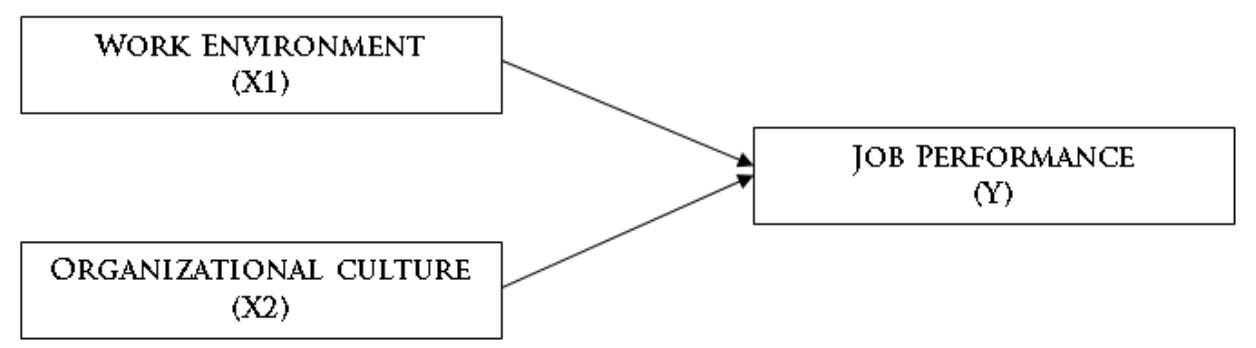

Figure 1

Research Conceptual Framework

The source is processed by the researcher, 2020

The basis for establishing a hypothesis is based on previous research from Chandrasekar (2011); Imran et al. (2012); Djuremi et al., (2016); Mardikaningsih (2016); Saidi et al. (2019) who found that the work environment influences job performance. Besides that from previous research from Darsana (2013); Shahzad et al. (2013); Djuremi et al., (2016) who found that organizational culture influences job performance. Based on the theoretical foundation and the results of previous studies that have been described previously, the hypothesis in this study is (1) the work environment has a significant influence on job performance; (2) organizational culture has a significant influence on job performance; (3) the work environment and organizational culture have a significant simultaneous effect on job performance.

\section{RESEARCH METHODS}

Research on the influence of work environment and organizational culture on job performance using this type of explanatory research because it aims to test hypotheses that have been formulated previously. Explanatory research or explanatory research is research that seeks to explain causal relationships and examine the relationships that occur between facts and the development of human resources on job performance.

The questionnaire was distributed to 25 employees. The sample is a member of the population that can represent the characteristics of the population. The technique used to take the sample is total sampling, namely by taking all the population as respondents involved in work activities as many as 25 people so that the whole sample.

In identifying this variable the writer divides the two variables, namely the independent variable, the variable whose value affects the value of other variables. In this study the independent variables are the work environment (X1) and organizational culture (X2) while the meaning of the dependent variable is the variable whose value depends on the value of other variables. The dependent variable is job performance $(\mathrm{Y})$. The first independent variable is the work environment (X1) is everything that is around the employee and that can affect him to carry out the tasks assigned to him. Indicators of the work environment are (a) work relations in the 
office; (b) employee morale shown; (c) working room condition; (d) work facilities; (e) job comfort; and (f) cleanliness at work. The second independent variable is organizational culture (X2) is an important set of values, beliefs and understandings shared by employees. The indicators consist of: (a) mission; (b) consistency; (c) adaptation; and (d) employee involvement. The dependent variable is job performance (Y). Job performance is the results achieved by employees according to the measures applicable to the job or task for which they are responsible. Some performance indicators are (a) efficient work time, (b) work targets are achieved; (c) quality of work; (d) quantity of work.

The statistical analysis tool used in this study is multiple linear regression analysis because it involves two independent variables. To test the quality of the collected data, a validity and reliability test tool and a classic assumption test will be used. Data collection using a questionnaire involving Likert scale as a form of preference responses from respondents.

\section{Validity and Reliability Test}

\section{RESEARCH ANALYSIS AND DISCUSSION}

Validity test results are shown in Table 1 with the provisions declared valid if the value of the corrected item total correlation is greater than the value of 0.3 . Table 1 shows that all research variables were above 0.3 . Thus each item of question on the research variable is declared valid.

Table 1

Validity Test

\begin{tabular}{|c|c|}
\hline Indicators & Validity Value \\
\hline $\mathrm{X} 1.1$ & 0,544 \\
\hline $\mathrm{X} 1.2$ & 0,525 \\
\hline $\mathrm{X} 1.3$ & 0,847 \\
\hline $\mathrm{X} 1.4$ & 0,779 \\
\hline $\mathrm{X} 1.5$ & 0,562 \\
\hline $\mathrm{X} 1.6$ & 0,441 \\
\hline $\mathrm{X} 2.1$ & 0,664 \\
\hline $\mathrm{X} 2.2$ & 0,604 \\
\hline $\mathrm{X} 2.3$ & 0,599 \\
\hline $\mathrm{X} 2.4$ & 0,694 \\
\hline $\mathrm{Y} .1$ & 0,753 \\
\hline Y.2 & 0,674 \\
\hline Y.3 & 0,714 \\
\hline Y.4 & 0,556 \\
\hline
\end{tabular}

Source: SPSS Output

Next is reliability testing to show the extent to which the gauges can be trusted to analyze data. For the first independent variable namely the work environment (X1) obtained an alpha value of 0.605 ; the second independent variable is organizational culture (X2) of 0.625 ; and the dependent variable is job performance of 0.677 as shown in Table 2. Thus, the question items related to the research variables are declared reliable. List of questions about research variables can be trusted to analyze further data. 
Table 2

Reliability Test

\begin{tabular}{|c|c|}
\hline Variables & Alpha Value \\
\hline Work Environment (X1) & 0,605 \\
\hline Organizational Culture (X2) & 0,625 \\
\hline Job Performance (Y) & 0,677 \\
\hline
\end{tabular}

Source: SPSS Output

\section{Classic Assumption Test}

Subsequent tests were performed with the classic assumption test consisting of normality, multicollinearity and autocorrelation tests. Normality test to find out the normal distribution of data collected. The figure shows that the points follow the diagonal line. The normal distribution will form a diagonal straight line and ploting data will be compared with the normal line. Thus it can be said that data distribution is normal.

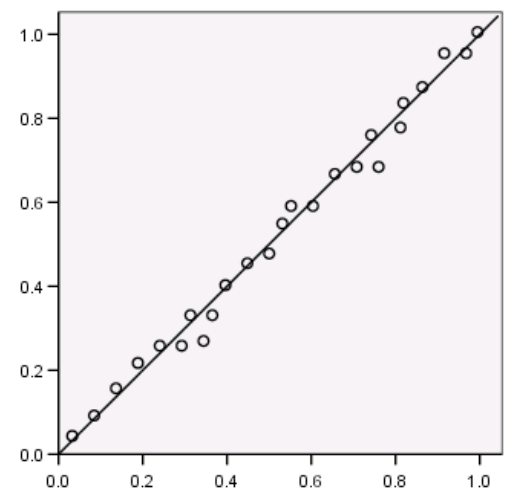

Figure 2

Normal Probability Plot

Source: SPSS Output

From the multicollinearity test, tolerance values and VIF values were obtained, each of 0.619 and 1.088. This shows that the tolerance value obtained is less than 1 and VIF between 1 and 2 then it can be said that the equation of a research model does not show symptoms of multicollinearity. From the autocorrelation test the Durbin Watson figure was 1.995. This is no autocorrelation problem because the number is between values 2 and -2 . Thus there is no autocorrelation problem.

\section{Hypothesis test}

To test the hypothesis two measurement tools are used namely the $\mathrm{F}$ test and the $\mathrm{t}$ test. $\mathrm{T}$ test to test the partial effect of independent variables on the dependent variable. The results of calculations using SPSS software as shown in Table 3 below.

Table 3

Coefficients $^{\mathrm{a}}$ 


\begin{tabular}{|c|c|c|c|c|c|}
\hline \multirow[b]{2}{*}{ Model } & \multicolumn{2}{|c|}{$\begin{array}{l}\text { Unstandardized } \\
\text { Coefficients }\end{array}$} & \multirow{2}{*}{$\begin{array}{c}\text { Standardized } \\
\text { Coefficients }\end{array}$} & \multirow[b]{2}{*}{$\mathrm{t}$} & \multirow[b]{2}{*}{ Sig. } \\
\hline & B & Std. Error & & & \\
\hline (Constant) & .857 & 2.144 & & .397 & .612 \\
\hline $\mathrm{X} 1$ & .571 & .122 & .586 & 4.600 & .000 \\
\hline $\mathrm{X} 2$ & .418 & .127 & .413 & 3.250 & .002 \\
\hline
\end{tabular}

Source: SPSS Output

Based on the results of this $t$ test is done by comparing the value of Probability sig. each independent variable with the specified limit is 0.05 . From the comparison results obtained by the value of P Sig. In the table, the value of 0,000 for the work environment independent variable (X1) is obtained, and the value of 0.002 for the organizational culture independent variable (X2), which means it is below the 0.05 limit. Thus it can be stated that at the real level $\alpha=0.05$, the independent variable has a partially significant effect on the dependent variable, namely job performance. The first and second hypotheses are proven correct.

F test to test the simultaneous effect of the independent variables on the dependent variable. The results of calculations using SPSS software as shown in the following table.

Table 4

ANOVA $^{\mathrm{b}}$

\begin{tabular}{|c|c|c|c|c|c|}
\hline Model & $\begin{array}{l}\text { Sum of } \\
\text { Squares }\end{array}$ & df & $\begin{array}{l}\text { Mean } \\
\text { Square }\end{array}$ & $\mathrm{F}$ & Sig. \\
\hline Regression & 72.471 & 2 & 36.236 & 56.543 & $.000^{\mathrm{a}}$ \\
\hline Residual & 10.245 & 22 & .639 & & \\
\hline Total & 82.728 & 24 & & & \\
\hline
\end{tabular}

Source: SPSS Output

Based on the results of the $\mathrm{F}$ test is done by comparing the value of Probability sig. with the specified limit is 0.05 . From the comparison results obtained by the value of P Sig. In the table, a value of 0,000 is obtained which means that it is below the 0.05 limit. Thus it can be stated that at the real level $\alpha=0.05$, the independent variable simultaneously influences the dependent variable. The third hypothesis was proven correct.

After all the hypotheses have been proven correct, a regression equation is formed which is formed as follows: $\mathrm{Y}=0.857+0.571 \mathrm{X} 1+0.418 \mathrm{X} 2$. From this equation, it can be seen that the dependent variable $\mathrm{Y}$ continues to increase by 0.857 along with the increasingly fulfilling of the work environment free variable (X1) of 0.571 and organizational culture (X2) of 0.418 .

From this equation, it can also be determined that the independent variable that has dominant influence on the dependent variable is the work environment (X1), which is seen from the highest regression coefficient value among the other independent variables, namely organizational culture (X2). The value of the regression coefficient of the work environment (X1) is 0.571 or greater than the regression coefficient of the organizational culture variable (X2) of 0.418 . Work environment variable (X1) is the independent variable that has the most dominant influence on the dependent variable. The coefficient of determination is shown from the SPSS output as in Table 5 below. 
Table 5

Model Summary

\begin{tabular}{|l|r|r|r|r|}
\hline Model & R & R Square & $\begin{array}{l}\text { Adjusted } \\
\text { R Square }\end{array}$ & $\begin{array}{c}\text { Std. Error of } \\
\text { The Estimate }\end{array}$ \\
\hline 1 & $.548^{\mathrm{a}}$ & .301 & .299 & .44965 \\
\hline
\end{tabular}

a. Predictors: (Constant), X2, X1

Source: SPSS Output

Based on the calculation results above, the $\mathrm{R}$ square coefficient of 0.301 indicates that there is a not too strong influence between the independent variable and the dependent variable. The determinant coefficient of 0.301 indicates that this multiple regression model whose independent variables consist of work environment (X1) and organizational culture (X2) has contributed $30.1 \%$ to the formation of the dependent variable, namely job performance. While the remaining $69.9 \%$ is determined by other factors.

\section{DISCUSSION}

Research findings lead to proof of research hypotheses. The first hypothesis states that the work environment has a significant effect on job performance. These findings support the results of previous studies from Chandrasekar (2011); Imran et al. (2012); Djuremi et al., (2016); Mardikaningsih (2016); Saidi et al. (2019). This proves that the existence of a good work environment will increase the enthusiasm and performance of its employees. Environments in the workplace that have met standards such as lighting, air circulation, safety and comfort and harmonious social interaction will improve job performance. Employees will show improved performance and complete the work assigned to them if conditions of work are comfortable. Empowerment is not only done for human resources, but it should also be done for the work environment. A work environment that has empowerment will have a positive impact on job performance (Hariani, 2017). The implication is to create a good environment, provide services ranging from security and safety at work so that it can provide its own satisfaction for employees and will improve performance in completing tasks that have been assigned to him.

The second hypothesis states that organizational culture has a significant effect on job performance. This finding is also in accordance with the results of previous studies from Darsana (2013); Shahzad et al. (2013); Djuremi et al., (2016). Organizational culture is considered important because a strong organizational culture can encourage employees to continue to improve their performance. The implication is to create good assumptions and good values for employees where this is intended so that the organization learns to overcome or deal with problems that can arise due to external adaptation and integration that are already running.

Thus based on the results of the hypothesis test it can be stated that with an optimal work environment and organizational culture it is expected to form optimal job performance as well. Diverse employee behavior requires the leadership of an organization to consider all the situations in which the behavior occurs, including the factors that influence it. In this research, 
it is proven that working conditions such as work environment and organizational culture have a significant influence on employee behavior and performance.

\section{CONCLUSION}

This study aims to determine the effect of the work environment and organizational culture on job performance. From the research findings described in the previous chapter, the author will establish several matters related to the conclusions in this study. The conclusions that can be determined are (1) the work environment has a significant effect on job performance; (2) organizational culture has a significant effect on job performance; and (3) work environment and organizational culture simultaneously have a significant effect on job performance

Based on the results of the discussion and conclusions that have been described, the authors propose the following recommendations: (1) job performance can be improved through efforts to improve the quality of the work environment and organizational culture in line with organizational goals. In addition, this can be realized through the role of leadership to support any activities related to the development of quality human resources obtained from the improvement of organizational systems and procedures; (2) the implementation of task activities strongly implies the need for improved performance. For employees with the opportunity given by the leadership to be able to develop their potential related to the overall development of human resources that they empower. This can be supported through compensation programs in the form of financial and non-financial as a form of implementing motivational programs derived from organizational and leadership policies; (3) the organization must continue to shape the culture of the organization through a variety of policies and behavioral arrangements for members of the organization so that it is expected to be able to support job performance to be more optimal and to foster high commitment from employees; (4) further research can be developed based on relevance to the topic of human resource management related to work conditions and worker behavior in organizations.

\section{REFERENCES}

Chandrasekar, K. 2011. "Workplace Environment and its Impact on Organisational Performance in Public Sector Organisations", International Journal of Enterprise Computing and Business Systems, 1(1), 1-19.

Darmawan, Didit. 2019. Pengantar Manajemen. Revka Prima Media, PT., Surabaya

Darmawan, Didit. 2013. Prinsip - Prinsip Perilaku Organisasi, Pena Semesta - PT. JePe Press Media Utama, Surabaya

Darsana, Made. 2013. "The Influence Of Personality And Organizational Culture On Employee Performance Through Organizational Citizenship Behavior". The International Journal of Management. Vol 2 Issue 4 (October, 2013).

Denison, D. R. \& Mishra, A. K. 1995. "Toward a Theory of Organizational Culture and Deffectiveness", Organizational Science. Vol.6, No.2, Pp. 204-23.

Djuremi., Leonardo, Budi, Hasiolan., \& Maria, Magdalena, Minarsih. 2016. "Pengaruh Lingkungan Kerja, Budaya Organisasi dan Kepemimpinan Kinerja Pegawai pada Dinas Pasar Kota Semarang”. Journal of Management. Vol.2, No.2. 
Dobre, Ovidiu-Iliuta . 2013. "Employee Motivation and Organizational Performance", Review of Applied Socio- Economic Research, Volume 5, Issue 1, pp. 53 - 60

Gunawan, Aditya. 2017. Manajemen Sumber Daya Manusia. Jakarta, MetroInsight.

Hariani, Mila. 2017. " Analysis of Worker's Response to the Empowerment of Human Resources in the Quality Control Section in the Export Activities of Rattan Production Results ", Agrimas Journal of Agribusiness, Vol.1 No.1 Juni, 19-28

Imran, Rabia., Fatima, Afsheen., Zaheer, Arshad., Yousaf, Imran and Batool, Iram. 2012. "How to Boost Employee Performance: Investigating the Influence of Transformational Leadership and Work Environment in a Pakistani Perspective". Middle-East Journal of Scientific Research. 11 (10): 1455-1462, 2012.

Jain, R., \& Kaur, S. 2014. "Impact of Work Environment on Job Satisfaction", International Journal of Scientific and Research Publications, 4(1), 1-8.

Kast, Fremont. E. \& Rosenzweig, James. E. 1990. Organisasi dan Manajemen. Bumi Aksara. Jakarta.

Kreitner, Robert \& Angelo, Kinicki. 2005. Perilaku Organisasi. Jakarta. Salemba Empat.

Luthans, Fred. 2011. Organizational Behavior. Irwin/McGraw-Hill. New York. United Stated of America .

Mahyanaila, Rahayu. 2016. Manajemen. Malang, Addar Press.

Mardikaningsih, Rahayu. 2016. " Leadership and Work Environment Variables and Their Effects on Employee Performance", Management \& Accounting Research Journal, Vol.1 No.1 November, 55-62

Saidi, Nur Shifaa Athirah., Florianna Lendai Michael, Helmi Sumilan, Sheilla Lim Omar Lim, Victoria Jonathan, Hana Hamidi \& Abg Izhar Abg Ahmad. 2019. "The Relationship Between Working Environment and Employee Performance", Journal of Cognitive Sciences and Human Development. Vol. 5(2), 14-22

Schein, E.H. 2004. Organizational Culture And Leadership. Jossey-Bass Publisher. San Francisco.

Schein, E. H. 1996. “Three Culturesof Management: The Key to Organizational Learning”, Sloan Management Review, 38(1), 920

Schultz D. \& Schultz, S. E. 2006. Psychology \& Work Today. New Jersey. Ninth Edition. Pearson Education. Inc.

Shahzad, Fakhar., Iqbal, Zahid and Gulzar, Muhammad. 2013. "Impact of Organizational Culture on Employees Job Performance: An Empirical Study of Software Houses in Pakistan", Journal of Business Studies Quarterly. Volume 5, Number 2.

Sinambela, Ella Anastasya., Yusuf Rahman Al Hakim, Moch Irfan. 2019. "The Effect of Discipline and Work Communication on Job Performance", Journal of Economics, Vol.15 No.2 July $308-320$

Walker, J. W. 1992. Human Resource Strategy. MCGraw-Hill International Editions. Singapore. 